\title{
Debunking the pathological model - The functions of an Internet discussion group
}

\author{
Robert S. P. Jones and Heledd Lewis \\ School of Psychology, University of Wales, Bangor
}

\begin{abstract}
In recent years there has been a profusion of resources about Down syndrome available on the World Wide Web and for increasing numbers of people the internet is the resource first contacted when new information is required on a topic. The present paper examined the function of a discussion group which is used primarily by parents of people with Down syndrome. Qualitative research methodology (content analysis) was used to analyse the daily discussions over a 5 month period in 1998 (February to July) and over a 2-week follow up period six months later (January 1999). The analysis revealed themes of celebration, seeing the child before seeing the handicap, hope and optimism, a sense of purpose in life and of being like a family within this group.
\end{abstract}

Keywords - Down syndrome, Internet, discussion group

\section{Introduction}

It has been suggested that the Internet could change the lives of average citizens as much as did the telephone in the early part of the 20th century and television in the 1950's and 1960s (Kraut et al., 1998). According to the Internet Industry Almanac there will be over 579 million computers in use by the end of the year 2000. The Almanac estimates that 26 million computers are in use in the United Kingdom alone.

In particular, the amassing of health information on the Internet and World Wide Web has continued to grow in recent years. Patients anxious to participate in decisions about their own treatment have turned to the Internet to confirm diagnoses, validate physician-recommended treatment, or seek alternative therapies (Bader \& Braude, 1998). Some publications even offer specific advice in designing web sites to maximise accessibility to the Internet for people with disabilities (Laux, 1998).

Many Internet sites are devoted to Down syndrome and there is evidence that these are increasingly being used, particularly by parents and, to a lesser extent, by professionals and people with Down syndrome themselves (a list of relevant international site addresses is available at http://www.dshealth.com/ds_sites.htm and a list of UK sites is available at http://www.43green.freeserve.co.uk/uk_downs_syndrome/ukdsinfo.html).
In addition to the many thousands of special interest sites available, the Internet contains many hundreds of electronic groups and mailing lists whose ostensible purpose is to discuss problems and to provide social support (Mickelson, 1997). Although little is known about the functioning and efficacy of these groups (Winzelberg, 1997), a limited number of recent studies have appeared.

Bowers (1997) reported the results of a content analysis of of discussions which took place on the psychiatric-nursing email list over a 16 month period. Similarly, Roberts and Fox (1998) explored the use of the Internet-based discussion group by 443 General Practitioners and their colleagues. They found that the group had features of a collaborative medium, in which the audience are also contributors There was also support for a 'critical mass' model, in which a relatively small number of members contribute on a regular basis.

Winzelberg (1997) performed a discourse analysis on 306 messages posted to an eating disorder electronic support group. The most common message content involved selfdisclosure $(31 \%)$ followed by requests for information $(23 \%)$, and the direct provision of emotional support (16\%). Six themes were identified in the content of the messages. The majority of members participated in the group during the evening and late night at a time when traditional sources of support have limited availability or are not available. 
Sharf (1997) explored the communication occurring on the Breast Cancer List, an on-line discussion group. She identified three major dimensions: exchange of information, social support, and personal empowerment. She concluded that the List fulfills the functions of a community, with future concerns about information control and the potential to enhance patient-provider understanding.

The present study explored the communications occuring on the Down Syndrome Discussion Group (the DOWN-SYN list hosted at listserv.nodak.edu). One description of the discussion group describes it as having “...100's (if not 1000's) of readers and many active participants, where every conceivable issue involving Down syndrome is eventually discussed" (Down Syndrome Resources on the Internet, 1998).

\section{Method}

Messages over a six month period (February to July 1998) were recorded and analysed using content analysis (Weber, 1995). Content analysis involves the segmenting of text into units that are then described by codes derived from the data itself. Over 140,000 words formed the raw data for the study and because of this large data set, different levels of analysis were used. It was found that after about two weeks worth of data coded, the number of categories developed decreased significantly. The primary analysis took place on the discussion for one month (March) and this led to five main content groupings.

Messages from the other five months of the study were read and these also were found to be most easily classified into these five headings. Seventy seven messages requesting help were randomly chosen from within the six month period and from a 5-month follow up (December 1999). These were examined to determine the time of day the messages were initially sent. This data was then divided into two categories: within working hours (weekdays 9.am-5.pm) and outside working hours. Finally, two weeks worth of messages from January 1999 (6-month follow up) were also analysed to check the robustness of the categorisation process.

\begin{tabular}{|c|c|c|c|c|}
\hline Advice & $\begin{array}{l}\text { Sharing Trials and } \\
\text { achievements }\end{array}$ & Information & Supportive & Expressing Views \\
\hline $\begin{array}{l}\text { - } \text { medical advice } \\
\text { - computer advice } \\
\text { - help with specific } \\
\text { problem } \\
\text { - developing } \\
\text { services / policies } \\
\text { - dealing with } \\
\text { professionals } \\
\text { - developmental } \\
\text { queries } \\
\text { - dealing with } \\
\text { discrimination } \\
\text { - new treatments / } \\
\text { aids }\end{array}$ & $\begin{array}{l}\text { - sharing personal } \\
\text { life stresses } \\
\text { - success in dealing } \\
\text { with } \\
\text { professionals } \\
\text { - developmental } \\
\text { breakthroughs } \\
\text { with kids }\end{array}$ & $\begin{array}{l}\text { - computer } \\
\text { information } \\
\text { - up and coming } \\
\text { events } \\
\text { - new policies } \\
\text { - groups } \\
\text { - books and videos } \\
\text { - available services / } \\
\text { aids } \\
\text { - medical } \\
\text { information / } \\
\text { treatment }\end{array}$ & $\begin{array}{l}\text { - support through } \\
\text { major life events } \\
\text { - congratulations } \\
\text { - support in starting } \\
\text { new ventures } \\
\text { - support for good } \\
\text { parenting } \\
\text { - support against } \\
\text { societal } \\
\text { discrimination } \\
\text { - support for future } \\
\text { and new parents }\end{array}$ & $\begin{array}{l}\text { - policies } \\
\text { - discrimination } \\
\text { against people } \\
\text { with Down } \\
\text { syndrome } \\
\text { - health and } \\
\text { educational } \\
\text { professionals } \\
\text { - giving alternative } \\
\text { explanations for } \\
\text { upsetting events } \\
\text { - clarifying } \\
\text { provocative } \\
\text { statements } \\
\text { - services }\end{array}$ \\
\hline
\end{tabular}

Table I: Major themes and sub categories

\section{Procedure}

The content analysis was performed in order to abstract categories from the data. It was decided that categories should be mutually exclusive so messages were cut and pasted from the database and into these different files immediately to avoid the dilemma of the same message being saved in different categories. Where messages were relevant to more than one category, the greater number of words used determined the category assignment.

During the reading of the March 1998 messages, initial categories were formed and then refined. Following this the categories were analysed for their different component functions, using the same method. As a way of assessing the reliability of categorisation, operational definitions of each category were drawn up and a second rater assigned randomly selected messages into these categories.

\section{Time of messages}

Of the 77 'help' messages 56 (73\%) were posted outside working hours. In other words the majority of parents requesting help did so at times when it would have been difficult to obtain assistance using alternative methods. For example one evening at 11.22 a father requested immediate help preparing for his child's school review in two days time:

Hi Gang. This usually quiet lurker is suppressing fullthroated screams after this afternoon attending what is now Part One of our son's ARD meeting (Admission and Review Determination--our county's term for the IEP process). I need some quick feedback as we reconvene on Wednesday (20th) to continue the leftovers from today's 1.5 hours. (May 1998).

Sixteen people replied with suggestions and advice within the next 24 hours and over 40 messages on the topic were posted within the next week. This rapid ability to obtain help is a feature of the discussion group and was commented upon by a number of people. One mother wrote:

\section{Results}


I would like to say thank you to all of you who responded to my original posts. WOW!!! So much advice and all of it very good advice. (May)

Another topic elicited the following:

This is the greatest thing (cyper friends) since neighborhoods!!

$$
\text { All I had to do was ask and help came running!! (May) }
$$

\section{Content Analysis}

The group members exchanged information on medical matters, child development matters, new treatments and aids, services, policies and groups, professionals (educational and health), discrimination against people with Down syndrome, personal life stresses, up-and-coming

\begin{tabular}{|c|c|}
\hline Meta-theme & Example \\
\hline Celebration & $\begin{array}{l}\text { "I just had to tell someone. N. did } \\
\text { his first sign!!!!!! (HUGE SMILE). We } \\
\text { have been working on it for a couple } \\
\text { weeks now. He did the sign for } \\
\text { 'more'. I am so excited. I am teaching } \\
\text { myself sign from a site I found on } \\
\text { Internet (Jan, I999) }\end{array}$ \\
\hline $\begin{array}{l}\text { Seeing the child before } \\
\text { the handicap }\end{array}$ & $\begin{array}{l}\text { "You know, I don't care that < the } \\
\text { GP> didn't notice Emily has Down } \\
\text { syndrome, what makes my day is that } \\
\text { I FORGOT to write it down!!!!!!". } \\
\text { (March, 1998). }\end{array}$ \\
\hline Hope and optimism & $\begin{array}{l}\text { "Thank you B. for this wonderful } \\
\text { note, the tears are still flowing over } \\
\text { my computer. M. is } 22 \text { months and I } \\
\text { often worry about him in later years } \\
\text { with school etc. I just love hearing } \\
\text { these inspirational stories, with each } \\
\text { one my worries seem to lessen. Way } \\
\text { to go T., you should be so proud!!!!!" } \\
\text { (July, 1998). }\end{array}$ \\
\hline $\begin{array}{l}\text { The role of the } \\
\text { discussion group }\end{array}$ & $\begin{array}{l}\text { "...like we are soulmates or members } \\
\text { of some exclusive club" (March, } \\
\text { 1998)."There are plenty of people } \\
\text { who read without posting and seeing } \\
\text { all the congratulations posted here } \\
\text { may be just what *they* need. Seeing } \\
\text { the parents here treat the birth of } \\
\text { a child with Down syndrome as } \\
\text { something wonderful may make them } \\
\text { feel better even if the comments } \\
\text { aren't directed to them" (Feb, 1998). }\end{array}$ \\
\hline $\begin{array}{l}\text { Parents as agents for } \\
\text { change }\end{array}$ & $\begin{array}{l}\text { "Maybe the only way } \\
<\text { discrimination> can be changed is } \\
\text { by writing a letter to the News Paper } \\
\text { and making it public, that may be } \\
\text { the best way to get it started. You } \\
\text { know that people perish for lack } \\
\text { of knowledge. I stand on that, how } \\
\text { about you?" (March, 1998). }\end{array}$ \\
\hline $\begin{array}{l}\text { A validating and } \\
\text { supportive environment }\end{array}$ & $\begin{array}{l}\text { "I know the heartbreak you feel and } \\
\text { if you ever need to talk privately, } \\
\text { please e-mail me. Try to take care of } \\
\text { yourself and your family. My prayers } \\
\text { are with you" (July, 1998). }\end{array}$ \\
\hline
\end{tabular}

events, books and videos, and computers. This swapping of information took many different forms and five general categories emerged from the content analysis. Parents shared personal trials and achievements, gave advice, shared information, supported each other and expressed personal opinions. Each category contained the themes illustrated in Table 1.

\section{Meta themes}

Six meta-themes emerged from the content analysis and serve as a backdrop against which the above themes can be discussed. The meta-themes are a sense of celebration, seeing the child before the handicap, a sense of hope and optimism for the future, parents as agents of change, the role of the discussion group, and a constantly validating and accepting environment. Examples of these meta-themes are illustrated in Table 2.

\section{Reliability measures}

The operational definitions and a random sample of the e-mails were given to an independent rater who was asked to categorise the sample into the five areas outlined in Table 1. An agreement rating of $81 \%$. was achieved.

\section{Discussion}

The close analysis of the interactions on this discussion list confirmed the description of this group as being a place where 'every conceivable issue involving Down syndrome is eventually discussed' (Down Syndrome Resources on the Internet, 1998).

The discussion group serves a number of positive functions for its members and there is clear evidence that it extends the boundaries of the social community for those who subscribe to it. It serves as a place where parents can request information, share experiences and obtain advice. Moreover there is a sense of shared identity and mutual support in many of the interactions.

I have read several of your posts about your daughter J and I just wanted to tell you how much I admire what you are trying to do for and with her. (July, 1998).

What is particularly striking is the sense of celebration and positive affirmation which pervades the discussions. New members are congratulated on the birth of their child and immediately provided with a network of optimistic and encouraging parents willing to share their own exeriences:

You will get through it just like we all have had to balancing the joy and the usual fear of the unknown. C. and his older brothers and his beautiful sister have a life time of experiences that they say has made their life unique and fulfilling because of him. That is not to say that our family has had an easy life, but you should see them NOW! (Jan, 1999)

The group also functions as a resource for people requesting information on Down syndrome although the responses are sometimes harsh:

My name is Jamie and I'm doing a research paper for my special education class at school. Could anyone give me 
any information that would be of help in my paper that would give the general population that may not know about DS a little more information about the disease? Thanks a LOT!! :>)

$J$ (24th Feb 1998)

J. - First thing you should learn about Down syndrome is that it is NOT a disease!

C. (25th Feb 1988)

When talking about the role of the group, members constantly alluded to the positive functions it played in their lives:

Congratulations on your new baby w/DS. How fortunate you are to have this group to get information from. Wish I'd had this 4 yrs. ago. You'll learn so much...just remember your little one is more like any other baby than not. (March, 1998).

Anybow, as a parent, I must say I have received a lot of support from this list... and love... and help.... and priceless information. (July, 1998).

On occasion a discussion develops into an argument or 'flame war' which can result in quite negative feelings from parents and although a significant majority of comments about the role of the group are positive, there are some exceptions:

I believe that I will be finished subscribing to the Down syndrome list in the very near future. I am very disappointed in the level of support that is offered here for and by parents. (July, 1998).

I joined this list to learn, to be able to help the families and children that I work with. I thought that hearing the opinions and experiences of families with loved ones who have DS would be a wonderful experience. Instead I am constantly amazed by the personal attacks and animosity. (July, 1998)

These, however, are very much in the minority:

Just when I get ready to sign off because of these 'wars' I then read something wonderful or people band together to lend a family support. I just wish we could leave all the crap behind. (April, 1998).

I have been on the list for 2.5 years - never have I felt that there is no support. quite the contrary. I feel that I can post a question or concern anytime and have support from many many folks here. yes, sometimes there is bickering. that's what makes us a family (July, 1998).

The group is often described as a family and seems to share many of the functions of such a close relationship:

Guess this is REALLY like one big family. I see alot of arguing here that seems to go on in our actual home lives. Hope you can work things out and soon. Love the Listserv, but don't need all the hostility. We all have our own opinions that we should all just listen and respect. (June, 1998).

\section{Conclusions}

While increased information for patients has been linked to improved outcomes (Bader \& Braude, 1998), many professionals point to the kind of inherent dangers associated with the kind of unauthenticated information available on the Internet. These centre on the lack of the peer review process and any form of editorial control over many articles which appear on the Internet thus allowing anecdotal and unbalanced information to be published (Pereira \& Bruera, 1998). The discussion group frequently contains examples where such information is passed between parents and often opinions about information available on the internet (e.g. targeted nutrition) is the source of some of the most contentious debates in the group. Parents are very aware of the reactions of professionals:

$O f{ }^{*} A L L^{*}$ the doctors I have dealt with personally, ${ }^{*} A L L^{*}$ frown when I mention 'Internet'. They say, "Don't believe everything you read on the Internet." And, I reply, "I

know, that's why I'm asking you” (Jan, 1999).

Professionals can no longer ignore the Internet as a major source of information concerning health-related issues for the general population. Rather than discourage the use of such technology, the answer perhaps lies in using the Internet to supply accurate information to parents. Bader and Braude (1998) recommend that the academic health sciences community seize the opportunity to take the lead in ensuring that patients have access to reliable health information, and suggest that "patient informatics" be integrated by academic physicians and educators into the teaching of clinical skills.

In particular, professionals need to be aware that not only is the 'pathological model' deeply offensive to many parents but that it is also simply inappropriate. Cunningham (1996), for example recently summarised many years of investigation into families with Down syndrome by concluding that:

It cannot be assumed that the family or individual members are 'at risk' for psychological problems just because one member has Down syndrome. We found that the majority of families (60-70\%) in the cohort were harmonious with high levels of family cohesion and perceived satisfaction with life and relatively normal levels of stress. They had adapted positively to their child with Down syndrome and report no persistent negative psychological effects on their lives or their other children. In fact they were more likely to feel the child had positively contributed to the family. (Cunningham, 1996).

In this analysis of the Down syndrome discussion group, this positive adaptation can be seen occuring on a dayby-day basis. Quite apart from the obvious benefits to parents themselves, professionals could learn a great deal by becoming a participant observer of such a group 


\section{Correspondance}

Dr. Robert Jones, Senior Lecturer in Clinical Psychology, School of Psychology, University of Wales, Bangor, LL57 2DG, North Wales. UK • Telephone:+44 248382205 - Fax: +44248383718•E-mail: r.s.jones@bangor.ac.uk

\section{References}

Bader, S. A. \& Braude, R. M. (1998) "Patient informatics": Creating new partnerships in medical decision making. Academic Medicine, 73, 408-411.

Cunningham, C. (1996). Families of children with Down syndrome. Down Syndrome Research and Practice, 4, 87-95.

Bowers, L. (1997). Constructing international professional identity: What psychiatric nurses talk about on the Internet. International Journal of Nursing Studies. 34, 208-212.

Kraut, R., Patterson, M., Lundmark, V., Kiesler, S., Mukophadhyay, T., \& Scherlis, W. (1998) Internet paradox: A social technology that reduces social involvement and psychological well-being? American Psychologist, 53, 1017-1031.

Laux, L. (1998). Designing Web pages and applications for people with disabilities. In Forsythe, C., Grose, E. \& Ratner, J. (Eds) (1998). Human factors and Web development. Mahwah, NJ, USA: Lawrence Erlbaum Associates.

Mickelson, K. D. (1997). Seeking social support: Parents in electronic support groups. In Kiesler, S. (Ed). Culture of the Internet. Mahwah, NJ, USA: Lawrence Erlbaum Associates, Inc.

Pereira, J. \& Bruera, E. (1998). The Internet as a resource for palliative care and hospice: A review and proposals. Journal of Pain and Symptom Management 16, 59-68.

Roberts, C. \& Fox, N. (1998). General practitioners and the Internet: Modelling a 'virtual community'. FamilyPractice, 15, 211-215.

Sharf, B. F. (1997). Communicating breast cancer on-line: Support and empowerment on the Internet. Women and Health, 26, 65-84.

Weber, R. (1995). Basic Content Analysis. Sage, California.

Winzelberg, A. (1997). The analysis of an electronic support group for individuals with eating disorders. Computers in Human Behavior. 13, 393-407. 